\title{
APUNTES LEXICOGRÁFICOS: A PROPÓSITO DE DISPENDIAR
}

\author{
FÉLIX RODRÍGUEZ GONZÁLEZ \\ Universidad de Alicante \\ Felix.Rodríguez@ua.es
}

A finales de diciembre de 2007, en una prueba celebrada en la Universidad de Alicante se incluyó una pregunta cuya contestación exigía conocer la presencia en nuestro idioma del verbo dispendiar. Al no estar recogido el vocablo en el diccionario de la RAE, la pregunta generó cierta confusión y fue cuestionada, planteándose así un conflicto de tipo jurídico y lingüístico. Este hecho lleva a hacernos unas reflexiones sobre el uso y registro de nuevas voces en la lengua, de interés para lexicógrafos y terminólogos, pero también para el hombre de la calle ${ }^{1}$.

En primer lugar, se comprende la reacción defensiva de los que se movieron por un sentimiento "atávico" que les llevó a valorar la presencia de una palabra en el diccionario académico como único criterio de autoridad. Es lo que ha venido siendo la práctica común para el lego y el público general, y más cuando se trata de una palabra supuestamente rara y perteneciente a un registro escrito y elevado.

Pero también, y con mayor motivo, hay que comprender la posición contraria, la del que ha contestado con acierto y defiende la reinclusión de dicha pregunta. Y es que la recopilación llevada a cabo en un diccionario como el de la Real Academia Española (DRAE), con todos mis respetos y valoración para el buen hacer de esta institución, es de tipo normativo, prescriptivo, pero está reñida con la doctrina del uso, la más acorde con la exigencias de la lexicografía moderna. Los ejemplos en defensa de esta tesis serían muy abundantes.

Al hilo de los anglicismos del español, asunto al que dediqué el primero de mis diccionarios, me permito recordar que las palabras software y hardware estuvieron en boca de informáticos y el usuario común de la informática durante años mientras la Academia proponía su sustitución por expresiones castizas, como soporte lógico y soporte físico, respectivamente. Pero la recomendación no contó con muchos adeptos, de manera que el uso terminó imponiéndose aun cuando las voces inglesas tienen una morfología extraña y una difícil y variable pronunciación, hasta el punto de que aún no han sido adaptadas al idioma. Es un caso extremo pero muy ilustrativo de cómo la Academia, como ocurre con tantas instituciones, siempre va a remolque de los cambios que se operan en la sociedad.

Podría igualmente aportar numerosos ejemplos extraídos de otros diccionarios míos: de la terminología militar (2005), la homosexualidad (2008) y la drogadicción (en prensa), así

\footnotetext{
${ }^{1}$ Una versión reducida de este artículo fue publicada en el diario Información del 8 de enero de 2008, pág. 18 ("El lenguaje, “casus belli”: a propósito de dispendiar”).
} 
como de otro en el que estoy trabajando, de interés más general, sobre el sexo y el erotismo. En todos ellos aparecen voces que están en la calle, que han ido adquiriendo carta de ciudadanía léxica, pero que no han sido incorporadas aún en el DRAE, simplemente porque no todas pueden entrar, por una cuestión de oportunidad y metodología. Se podrá argüir que pertenecen a un léxico más o menos especializado, pero es fácil constatar también el paulatino y constante trasvase de voces de la lengua especializada a la lengua general. ¿Y qué decir de voces populares, de argot, como kilo ('millón' de las antiguas pesetas) y taco ('año de edad'), que tardaron años en recogerse en el Diccionario manual ilustrado de la lengua española, el hermano menor del DRAE, y unos cuantos más en el propio DRAE?

Pero, ciñámonos ahora a nuestro “casus belli”, el verbo dispendiar, que tiene el significado de 'gastar, despilfarrar, derrochar'. Aun admitiendo su carácter restringido y escaso uso (aunque menos escaso de lo que a primera vista pudiera parecer), a todas luces pertenece a la lengua general, y por esa razón aparece prácticamente en todas las épocas de la historia de nuestra lengua y en diversos géneros literarios. Afortunadamente, en nuestros trabajos de lexicografía y terminología disponemos hoy de herramientas informáticas que nos permiten rastrear el curso de las palabras y, por tanto, apoyar lo que decimos, acudiendo a buscadores y bancos de datos que están al servicio de todos, incluidos los de la misma Real Academia Española (tanto el CREA, Corpus de Referencia del Español Actual, como el CORDE, de carácter propiamente histórico), cuya labor lexicográfica, no olvidemos (y a la vista está), no se ciñe exclusivamente al Diccionario. De este modo, se puede comprobar que la palabra está documentada ya en épocas muy antiguas (por citar un ejemplo, Juan de Ortega en 1512 se refirió en un escrito a un mercader que “dispendió 6 ducados”). Y en tiempos ya contemporáneos, Rosa Chacel emplea la palabra en su novela Barrio de maravillas (1976), y más reciente aún, el escritor Juan Bonilla, en El que apaga la luz (1994) habla de "dispendiar el dinero". Mayor valor documental tiene todavía un ejemplo tomado de la prensa general, de un periódico de los llamados de calidad, como es El Mundo, que, en su editorial de 27 de mayo de 1998 “Erecciones por las nubes”, hablando de gastos farmacéuticos y del Viagra, comenta que "ahora sí se puede dispendiar en este medicamento".

Echando una mirada ahora a los diccionarios, siempre más conservadores en el registro de las palabras, observamos que en el DRAE sí figuran el sustantivo dispendio (el más usual, del que el CORDE ofrece nada menos que 199 ejemplos y el CREA 109) y el adjetivo dispendioso, y en el Moliner ( $3^{\mathrm{a}}$ edición) el adverbio dispendiosamente. El Diccionario del Español Actual (DEA) de Manuel Seco (y colaboradores), sin duda el más extenso e importante diccionario de uso de nuestra lengua, recoge además dispendiador, y aporta dos citas. Y claro, dispendiador, al igual que dispendio, son sustantivos de los denominados "postverbales", es decir, formados previamente a partir de un verbo, al que deben su existencia. Es evidente que si uno es un dispendiador es porque dispendia, de la misma manera que si existe un gasto o un gastador es porque alguien se ha dedicado a gastar ¿ $\mathrm{O}$ acaso podríamos concebir la voz madrugada sin tener presente antes el verbo madrugar, aunque los lexicógrafos no lo hubieran registrado? (Por cierto, el inglés no tiene estos problemas; en esta lengua, mucho más plástica que la española, cualquier palabra, y no solo el sustantivo, virtualmente puede asumir otras funciones sintácticas, y sobre todo 
verbales, sin necesidad de añadir flexión alguna. Así, de $O K$ 'de acuerdo' pasan a hablar del verbo to $O K$, to okay 'dar el visto bueno, dar el OK'.

Claro que alguien también, con cierta lógica, se preguntará por qué M. Seco recoge entonces dispendiador y no dispendiar. La respuesta es sencilla: el diccionario fue publicado en 1999, y terminado unos años antes, una verdadera obra de artesanía, construida en su mayor parte a partir de las tradicionales "papeletas", o fichas, como en su día hiciera también María Moliner al elaborar su no menos famoso diccionario. Había, pues, un problema humano, y de técnica; los prodigios de la informática que conocemos hoy llegarían después.

Y lo mismo podemos decir del diccionario académico, que, como decía antes, no siempre está actualizado. ¿O acaso uno piensa que la próxima edición del DRAE, prevista para 2013, para conmemorar el tercer centenario de la institución, no va a incluir sugerencias y datos que ahora mismo ya están en circulación y en los próximos años pueden ser moneda corriente? Es decir, el hecho de que una palabra no esté registrada no quiere decir que no tenga vigencia.

Y luego está el escrúpulo legítimo del lexicógrafo riguroso, sobre todo si se trata de un diccionario de uso, no normativo, y más aún si recurre a las citas para su ilustración. En cierta ocasión, Manuel Seco me comentó que una palabra debería registrarse, a efectos lexicográficos, cuando al menos apareciera dos veces en documentos distintos, por obra de dos escritores (o hablantes) distintos y en dos momentos también diferentes. Condición que, de paso, cumple bien nuestra palabra en cuestión.

Para terminar está el problema de la definición y delimitación del español. Vivimos, sobre todo en nuestros días, en un mundo globalizado donde las palabras fluyen de un lado a otro del Atlántico, y por eso el diccionario académico, con un sentido práctico, incorpora voces provenientes de otras variedades del español, como las empleadas en Hispanoamérica, los llamados americanismos. Claro que no todas, por exigencias de espacio claramente comprensibles. Pero son voces que a diario nos encontramos en nuestro solar patrio (pensemos por ejemplo en pibe, del español de Argentina, o en el cubanismo jinetera) y se convierten en patrimonio común de los hispanohablantes, por no citar el creciente número de inmigrantes procedentes de esas latitudes -varios millones- que integran también la población española. Y traigo esto a colación precisamente por haber observado que el verbo dispendiar es más usual en el español de América. Como tal aparece recogido en algunos diccionarios, como es el caso de un diccionario de guatemaltequismos de 1941 y otro de venezolanismos de 1994.

Como colofón, y a riesgo de ser reiterativo, interesa no olvidar que el caudal de voces incorporadas en la lengua es incesante, y que los diccionarios y en especial el DRAE cumplen una función notarial, pero, por muy exhaustivos que pretendan ser en su registro, y aun limitándose a la lengua general, no pueden abarcar el uso en su totalidad, por lo que se impone algún tipo de filtro. Ello no quiere decir que las voces no filtradas carezcan de uso en la lengua. Por otro lado, es cierto que la renovación constante de la lengua exige introducir continuos cambios en el registro lexicográfico, desplazando voces obsoletas y de poco uso e incorporando otras que van ganando en frecuencia, pero la actualización de los 
diccionarios es un reto y un ideal nunca alcanzable pues cuenta con sus propias limitaciones, de tiempo y espacio. 